\title{
Conflict Vulnerability Assessment of the Southern Highlands Province
}

\section{Neryl Lewis}

The Southern Highlands Province (SHP) is undoubtedly Papua New Guinea's worst performing province. It is abundant in natural resources and its provincial budget is one of Papua New Guinea's highest, yet services barely operate and human development indicators are amongst the lowest in Papua New Guinea. Whilst conflict has always been a part of life in SHP, since the late 1990s the incidence of violent conflict and crime has increased markedly. Correlating with this rise in violence has been a serious decline in governance standards and an associated deterioration in basic service delivery.

This chapter seeks to provide a Conflict Vulnerability Assessment of SHP. ${ }^{1}$ As such its main objectives are to identify the key sources or drivers of conflict in SHP and to identify the issues that have the potential to further inflame conflict or promote peace and stability.

A modified version of the Country Indicators for Foreign Policy (CIFP) Risk Assessment Template ${ }^{2}$ was utilised as a framework for this assessment. CIFP attempts to apply rigour to the process of conflict risk assessment by analysing a country's situation against internationally identified conflict risk indicators.

Specifically, this report is structured around seven of CIFP's leading conflict risk indicators, namely:

- historical factors;

- political/governance factors;

- security sector factors;

- social factors;

- economic factors;

- environment and natural resource factors; and

- international factors (see Table 13.1).

As peace-conflict dynamics are fluid, this vulnerability/risk assessment will be subject to ongoing review and refinement. It should therefore be considered as a preliminary diagnostic only, providing a foundation for ongoing analysis and monitoring of peace-conflict dynamics in SHP. 


\section{Historical factors}

\section{Assumption}

Repeated episodes of violent conflict and lawlessness indicate propensity to resort to violence to air grievances/ resolve disputes.

\section{Table 13.1. Summary of conflict risk indicators for Southern Highlands}

\section{Province}

\begin{tabular}{|c|c|c|}
\hline Clustered Conflict Risk Indicators & Key issues in SHP & Level of Concern \\
\hline 1. Historical factors & $\begin{array}{l}\text { - } \quad \text { Tradition of tribal fighting } \\
\text { Effectiveness/applicability of traditional conflict } \\
\text { resolution mechanisms diminished in } \\
\text { contemporary nation-state }\end{array}$ & Medium \\
\hline 2. Political/governance factors & $\begin{array}{l}\text { - Patronage model of governance and corruption } \\
\text { inter-group rivalries for political and resource } \\
\text { control } \\
\text { - Service delivery breakdown } \\
\text { - } \text { Moribund public service } \\
\text { - Eack of national government intervention } \\
\text { providence of non-government service } \\
\text { - Lack of information (media) } \\
\text { - Separatist sentiment - Hela Province } \\
\text { movement }\end{array}$ & High \\
\hline 3. Security sector factors & $\begin{array}{l}\text { - Endemic lawlessness } \\
\text { - Competency and size of police service } \\
\text { - Proliferation of small arms }\end{array}$ & High \\
\hline 4. Social factors & $\begin{array}{l}\text { - High level of language group (tribal) diversity } \\
\text { Declining standards of living } \\
\text { - Poor human development indicators } \\
\text { opportunities } \\
\text { oppont/income generating } \\
\text { - Youth bulge } \\
\text { - High poponce against women } \\
\text { - 'Ouick' development } \\
\text { - HIV/AIDs }\end{array}$ & High \\
\hline 5. Economic factors & $\begin{array}{l}\text { - Relatively large provincial cash flows from } \\
\text { resource sector } \\
\text { - Reliance on resource sector for provincial } \\
\text { revenue (small agricultural sector) } \\
\text { - Skewed income distribution } \\
\text { - Criminal encroachment on the informal } \\
\text { economy }\end{array}$ & High \\
\hline $\begin{array}{ll}\text { 6. } & \text { Environmental and natural } \\
\text { resource factors }\end{array}$ & $\begin{array}{l}\text { - Land/resource ownership } \\
\text { - Land pressure and growing food security } \\
\text { issues }\end{array}$ & Low \\
\hline 7. International factors & $\begin{array}{l}\text { - } \quad \text { Lack of donor engagement in SHP } \\
\text { - Proximity to instability/conflict in neighbouring } \\
\text { - } \quad \text { illicit crovinces (Enga, Gulf, Western) } \\
\end{array}$ & Low \\
\hline
\end{tabular}




\section{Tradition of tribal fighting}

- Fighting is viewed as a legitimate means of prosecuting claims and exacting retribution for 'wrongs'. However, traditional non-violent dispute resolution mechanisms exist and there is not typically an immediate recourse to violence.

- Probability of SHP-wide civil conflict low when a fight is triggered by localised dispute. This is because divergence in 'tribal identities' means that conflict in one part of SHP typically does not translate into conflict in other parts of SHP.

- Traditional disputes are, however, increasingly manipulated for political purposes (e.g. election campaigning), raising the potential for these conflicts to spread beyond localised areas. For example, it is possible that support for the creation of a Hela province in the 2007 elections could prove divisive if political leaders are successful in mobilising the public for or against the cause.

- Ready access to small arms has changed the character of contemporary tribal warfare and increased casualty rates (see security sector factors).

- SHP's Western regional administrator reports that there were 164 conflict-related deaths in the Tari area alone in 2003 and 40 such deaths between January and August 2004.

\section{Effectiveness/applicability of traditional conflict resolution mechanisms diminished}

- The transition to nation-state has diminished the influence of those traditional power structures that kept violent confrontation within certain limits, and has created a power vacuum in areas where the state's role is minimal and traditional authority has broken down.

- The Western justice system is about crime and punishment, whereas the Melanesian system is about crime and reparation (compensation). Disputes cannot be resolved and justice is not seen to have been done until compensation has been paid. For this reason, the magistrate in Mendi reports that awareness-raising is required to educate people about the legal system and the role of a magistrate (many think he 'makes up the law' rather than interprets it).

- Lack of state-consolidated power and capacity to intervene has meant that modern law and justice systems are a 'veneer, an overlay'.

- Tribal fights tend to be triggered by small disputes over 'pigs, land and women'. Village courts if they were functioning could most likely resolve these disputes before they escalate. Unfortunately village courts have largely ceased to function in SHP and those that are functioning have no power to enforce rulings. 
- Traditionally conflict sprang from the community level or 'bottom-up', but now many conflicts are triggered from the 'top-down' (being politically motivated), rendering traditional conflict resolution methods less effective.

- During the 1980s traditional leadership structures began to change, with more senior leaders devolving responsibilities to younger 'Western educated' males with better ability to interact with foreign resource companies.

\section{Trend}

Resort to violence for dispute resolution is a longstanding feature of SHP society. While conflict is usually localised and non-violent dispute mechanisms continue to function, the declining influence of traditional mechanisms and weakening state justice institutions (combined with increased access to firearms) indicate that the incidence of violent conflict is likely to increase - particularly when manipulated by provincial leaders for political purposes.

\section{Political/governance factors}

\section{Assumptions}

Poor performing political institutions and governance systems aggravate conflict risks; unrepresentative government, corruption, poor transparency and accountability, inadequate service delivery and lack of information can lead to a strong sense of injustice. Furthermore the denial of civil and political liberties increases the likelihood dissenting views will be expressed through violence.

\section{Patronage model of governance and corruption}

- Political office tends to be seen as means to gain access to state resources for oneself and supporters ('wantok'), with parliamentary and electoral systems unable to transcend local loyalties.

- SHP was the last area of Papua New Guinea to be colonised, giving Southern Highlands less time than other areas of Papua New Guinea to adapt to the introduced political systems.

- There is a degree of acceptance of bigman corruption - perception that one's elected leader is not so much a politician looking after SHP, but a politician looking after constituents personally.

- However, there are also increasing levels of public dissatisfaction with lack of service provision and unmet expectations, with the potential for this dissatisfaction to be mobilised by political agitators for violent political change. 


\section{Volatile electoral processes with intense inter-group rivalry for political and resource control}

- Stakes are high for political control of SHP's considerable resource wealth, fuelling inter-group rivalries particularly during election periods.

- The 2002 national elections led to violent conflict in SHP with the election results declared invalid in six of SHP's nine electorates due to widespread vote rigging, intimidation of voters, theft of ballot boxes and violence. These six electorates remained unrepresented in the parliament until supplementary elections were held in April 2003 (with 2,000 police deployed to uphold security).

\section{Service delivery breakdown}

- Provincial government funding for service delivery in SHP has decreased markedly in recent years. Many services are only operating on the basis of contributions from the national government, donors, church groups and resource companies.

- In the health sector continuing security problems threaten to close both Mendi and Tari hospitals. Mendi Hospital is operating but is overstretched, with surrounding aid posts not operating due to lack of funding or absent staff. Tari Hospital (serving about 250,000 people) is without a doctor and is operating as an outpatient clinic only.

- In education sector the provincial governor introduced a free education policy. Under this policy, a private firm (Treid Pacific) has been contracted to run all SHP schools. The policy has suffered from poor planning and insufficient funding, which has meant few schools have been able to operate effectively, and some not at all. There is also a shortage of teachers (though many are still on the payroll), with a generation of children in SHP's more remote areas having never attended school.

- In regard to policing, the national government has generally responded to increased conflict/crime in SHP with the short-term deployment of police mobile squads. These squads have generally been insufficiently resourced and reliant on assistance from the resource companies. RPNGC has 200 regular police (100 of these are Mendi-based). The provincial police commander (PPC) is not able to liaise with SHP's political leaders as most reside in Port Moresby (his only point of liaison is with churches and other community groups). Mobile squads are an unsustainable solution over the medium term.

- In the justice sector, SHP has insufficient magisterial services (one magistrate may still be Tari, but operating without provincial government support) there should be 12 magistrates. Village courts have not operated effectively since 1995 (when the Organic Law shifted from the national government to provincial governments responsibility for funding village courts). 


\section{Moribund provincial public service}

- Few of SHP's political leaders spend time in the province, instead residing in Port Moresby. As a result the public service lacks political direction and access to decision-makers.

- Many senior public servants are also absent from the province and it is claimed that all key decisions (e.g. the 2004 provincial budget) are made in Port Moresby.

- Public servants attempting to operate in the province are becoming increasingly agitated.

- Increasingly the public service is being politicised, with SHP MPs appointing supporters to positions within the SHP administration. This situation has led to multiple employees on the provincial payroll for single positions, rendering public administration of the province unmanageable. It is reported that political appointments have been made all the way down to the village court level. For example there are currently there are two provincial administrators occupying the single position - engaged by successive SHP governors. Also, there are disputes between the former and new politically-appointed district administrators in Ialibu and Tari.

- There are also claims that duly elected LLG presidents have also been replaced by political appointments.

- SHP public servants claim they fear losing their jobs if they are perceived to be critical of current SHP government practices, decisions and policies.

\section{Lack of national government intervention}

- The 2002 SHP audit, conducted by Pricewaterhouse Coopers, found that approximately $\mathrm{K} 50$ million had been misappropriated from provincial revenue by successive SHP governments over the audit period 1998-2002. There has been no effective follow-up by the national government on the report's findings.

- This lack of national government action following the audit report highlights serious capacity and commitment problems within Papua New Guinea central and prosecuting agencies, as well as complicity with SHP corruption. Several national government ministers and senior bureaucrats in Waigani were implicated in corrupt dealings with SHP's leaders.

- The Organic Law gives substantial power to provincial politicians, making it difficult for the national government to intervene in provincial affairs and suspend provincial governments without declaration of a state of emergency.

- Successive national governments have found it difficult to confront governance breakdown in SHP when the government has needed SHP MP support to retain power. 
- Growing fatigue within the national government to deal with the problems in the SHP with public servants feeling increasingly despondent, seeing little returns for their efforts.

\section{Emergence of non-government service providers}

- Resource companies operating in SHP (Oil Search and the Porgera Joint Venture [PJV]) have become a 'surrogate state', funding schools, health care and roads through community programs and the tax credit scheme. Whilst this can certainly be positive where companies refuse to operate through patronage, thereby allowing less powerful groups such as women's organisations more chance of gaining resources, it is also the case that resource companies cannot possibly meet service delivery expectations and needs in their entirety.

- Mine closures which are expected within the next decade will increase pressure for state services at a time when the resource base will already be diminished.

- Churches (mainly Catholic and Uniting churches) also play an important service delivery role in SHP. However, the mainstream churches also rely on national and provincial government funding (salaries and equipment) to fully function.

- The churches currently manage a considerable number of schools, health clinics and aid posts and would be prepared to take over more if the provincial government allocated staff to these aid posts.

\section{Lack of information (media)}

- Most Southern Highlanders have no access to media sources such as newspapers or radio. People rely on 'word of mouth' - information that can easily become distorted and rumours spread unchecked.

\section{Separatist sentiment - Hela Province movement}

- The Huli are the dominant language group (with an estimated population of $250,000)$ in the north-western corner of SHP and are the main proponents for the establishment of a separate Hela province.

- The proposed province would encompass all of SHP's major resource projects (located mainly in the west) and benefit flows from Porgera in Enga Province - making Hela Papua New Guinea's wealthiest province. Other groups in SHP see Hela as a push by the Huli to control the province's resource wealth.

- Lack of perceived legitimacy of the state (undermined by its inability to provide an adequate level basic services and corruption) has increased the push for greater autonomy for the Hela region.

- Several Huli MPs have lobbied in Waigani for the establishment of a separate Hela province. In mid-2003 Prime Minister Somare announced that there 
would be a Hela Province by 2007 (with National Alliance campaigning to maintain SHP MP support).

- This issue has the potential to incite conflict not only between the Huli and language groups to the east, but also between the Huli and other groups within Hela region, such as the Duna. Although they believe that the Huli, Duna, Hewa and Bogia peoples descend from a common ancestor called 'Hela', the Duna charge the Huli with forgetting their common links and believe that the establishment of a Hela province will mean the Duna will loose their unique identity. In reaction, many Duna instead advocate the establishment of a Duna Province.

\section{Trend}

Given the high stakes for political office, elections will likely continue to be periods of increased tension and conflict, with MPs remaining under pressure to distribute the benefits of office to supporters. The increase in political appointments in the public service will further increase dysfunction within the provincial administration. Lack of national government action to address corrupt practices by SHP leaders will continue to create a permissive environment for greed-driven conflict, while further service delivery breakdown will fuel grievance-driven conflict. Moves to establish a separate Hela Province will likely trigger conflict between Huli and neighbouring groups cut off from SHP's resource wealth, as well as between Huli and other groups within Hela who do not want to be dominated by the Huli.

\section{Security sector factors}

\section{Assumption}

The intrinsic relationship between stability and development objectives has led to growing awareness within aid agencies of the importance of a functioning security sector that is fully accountable to civilian authority. Excessive militarisation not only reduces investment in social sectors but may also indicate mobilisation of state resources for repression of minority/dissident groups.

\section{Endemic lawlessness}

- Warlordism may not (yet) be applicable to SHP as raskol gangs are still predominantly based on tribal affiliations (wantok) rather than gravitating around a warlord. However, crime gangs (such as the late David Agini's) indicate that crime gangs are beginning to operate beyond clan lines. These groups operate as mercenaries or 'guns for hire', with warring parties hiring gangs (who possess high-powered weapons) to fight on their side.

- Criminal networks can become powerful in lieu of the state. They build upon existing networks e.g. traditional marriage and trading links. 
- Raskol/criminal gangs have operated along the main trunk road (the only road connecting the west of the province to Mt Hagen in the east), particularly in the Nipa area. These road blocks have served both criminal purposes (to rob travellers, particularly those heading to or from Mt Hagen with cash) and warfare purposes between the Huli and the Nipa (with the Nipa blocking the Huli's access in and out of the province).

\section{Competence and size of police service}

- The current provincial police commander (PPC), Simon Nigi, has a good track record and is committed, but police service is overstretched and under-resourced. The population (over 500,000) to police (300 police) ratio is very low, making it impossible for the police to be effective.

- Police officers feel under-utilised and disaffected. Incidents of criminal gangs capturing police have further lowered morale and the police believe that they are 'outgunned' by these gangs.

- Low public confidence in police service - due mainly to poor police discipline (including incidence of police and criminal collusion) and an unwillingness by communities to cooperate and provide information to police out of fear of retribution from criminals.

- PNGDF deployment if state of emergency was declared in SHP could trigger further conflict if under-resourced and not well-managed (particularly considering the negative impact the PNGDF's deployment had on the Bougainville conflict).

\section{Proliferation of small arms}

- Most commercially-manufactured firearms in SHP have been leaked/stolen from PNGDF and RPNGC armouries, with many purchased by local MPs for supporters.

- Some evidence of illicit gun/drug trade operating in/through SHP, though views differ on the scale of this problem.

- Potential for increased cross-border small arms trafficking and further arms build-up, particularly given the growing demand for firearms in SHP.

- It is claimed that most adult males in SHP own home-made shotguns.

\section{Trend}

Heavy demands on finite police resources and the proliferation of small arms is overwhelming the capacity of the state to provide stability. However, the police service is probably better placed to deal with SHP's law and order problems than the PNGDF. The growing demand for firearms may lead to increased weapons and ammunition trafficking. 


\section{Social factors}

\section{Assumption}

Ethnic and religious divisions within society represent cleavages around which dissent may be mobilised, particularly where one identity group exercises its dominance to accumulate economic and political benefits. High population density and growth rates can also accentuate the risk of conflict by heightening competition for physical and social resources. Young, unemployed populations can be politically volatile and prone to violence, placing less trust in political institutions and traditional patterns of authority. A decline in living standards can fuel grievance and competition for development benefits, with a lack of confidence in the state's ability to provide essential services correlating with political instability and civil unrest.

\section{High level of language group (tribal) diversity}

- SHP is highly socially and linguistically diverse (with at least 16 distinct language groups in SHP). Such social diversity can inhibit widespread conflict as no one social group has the numbers to gain political monopoly.

- However, ethnic affiliation also acts as a conflict mobiliser - particularly where there is perceived inequality between neighbouring groups.

\section{Declining standards of living}

- Service delivery breakdown is a major source of tension. Coupled with this, perceptions of 'needs' have changed such that hospital care now widely considered a right. It is felt that people who have become accustomed to accessing services may be more likely to react to their withdrawal than those people who have only had sporadic access to services.

- Postal, banking, trade stores and telecommunications are not available having closed down across much of the province. This is largely due to increasing security concerns.

\section{Poor human development indicators}

- SHP has some of the lowest human development indicators for Papua New Guinea. For instance, literacy levels in SHP are estimated at 50 per cent for men and 30 per cent for women, while children are shorter and on average weigh $300 \mathrm{~g}$ less at birth than those in Papua New Guinea's other provinces. The 2000 national census found that child malnourishment was a serious and widespread problem in SHP. 


\section{Lack of employment/income generating opportunities}

- There are few employment opportunities in formal sector. The mining sector, for instance, generates little employment and there are few agricultural employment opportunities beyond subsistence farming.

- Household income levels in SHP are rated low to very low - on average household income is estimated to be K20 per annum.

- Youth unemployment is an increasing problem in SHP, as it is throughout Papua New Guinea.

- Frustration over lack of opportunity and poverty is a potential trigger for violence particularly amongst young men.

- It is difficult for many Southern Highlands to access markets - over 100,000 live in areas reachable by air and foot only. The residential pattern for most groups in SHP is one of scattered households, not nucleated village settlements, inhibiting conventional economic development.

- SHP has the lowest levels of agricultural cash-cropping income in the country (in 2002 SHP produced 830 tonnes of coffee worth K3.6 million and in 2003 produced 1,020 tonnes worth K4.61 million).

\section{Youth bulge}

- SHP exhibits many familiar demographic characteristics of developing countries around the world - high population growth rate with associated 'youth bulge'.

- A 'youth bulge' typically leads to high youth unemployment with an associated increase in criminality and other social maladies. It also puts pressure on traditional support mechanisms.

- Growing up without traditional clan support mechanisms but surrounded by trappings of modernity can lead to growing dissatisfaction and resentment. Youth alienated from traditional mechanisms for addressing grievances tend to be more likely to resort to spontaneous violence or criminality.

- Intergenerational conflict over royalty payments is of increasing concern in SHP, with the sons of landowners agitating for access to the benefits their fathers receive as the officially registered landowners (similar in this regard to the Bougainville conflict).

\section{Violence against women}

- Traditional attitudes of male dominance have been accentuated by lack of income-generating opportunities, leading to disenchantment and increased propensity to resort to violence against women.

- Belief in sorcery (sanguma) is common throughout SHP. Women are most often the victims of sorcery allegations and violent retribution. 


\section{High population growth rate}

- $\quad \mathrm{SHP}^{\prime}$ s annual average population growth rate is estimated at 3.5 per cent higher than Papua New Guinea's average.

\section{'Quick' development}

- Rapid resource development has created enclaves - with sharp economic and social difference between the 'haves' and the 'have-nots' (including intergenerational conflict between benefiting landowners and their sons).

- Anthropologists have also noted incidents where groups have started fights after receiving royalty payments in order to offer generous compensation and demonstrate their group's wealth.

\section{HIV/AIDS}

- The incidence of HIV/AIDS in SHP appears to be rising dramatically. This will inevitably have major economic and social implications for SHP.

- HIV/AIDS is little understood by general population in SHP.

- There are seemingly links between an increase in sorcery-related killings and a rise in HIV/AIDS incidence in SHP, with women predominantly being blamed for unexplained illnesses suffered by an increasing number of men.

- Mendi and Tari hospitals are equipped to conduct HIV testing but often lack the chemicals needed to conduct these tests. Smaller aid posts are not equipped to do such testing.

- SHP's Provincial Aids Council has performed poorly.

\section{Trend}

The rise in HIV/AIDS is of serious concern with far-reaching social and economic implications. Continued service delivery breakdown is also of humanitarian concern, with many Southern Highlanders unable to access basic medical care. Growing levels of dissatisfaction and agitation in SHP can render the population increasingly vulnerable to political manipulation - particularly with a large youth population.

\section{Economic factors}

\section{Assumption}

Economic decline and poor economic performance (including high debt burdens and inequities) reduce the capacity of the state to meet its obligations to citizenry, fuelling popular unrest and other preconditions for violent conflict, in particular scapegoating of economically privileged minorities. 


\section{Relatively large provincial cash flows}

- SHP has the largest provincial budget in Papua New Guinea. The provincial budget for 2004 totalled K96.5 million. Of this K40 million was allocated for salaries (including teachers), K24 million provided through the Tax Credit Scheme for development projects, leaving over K30 million for goods and services - substantially more than most other provinces.

- The national government, provincial government and incorporated landowner groups have all received large cash flows from the resource sector. From 1992 to 2003, Papua New Guinea's national government received an estimated \$US3 billion from SHP's resource companies. During the same period SHP's provincial government received over \$US282 million while landowner groups received over \$US1 billion.

\section{Reliance on mining sector for provincial revenue}

- SHP is highly dependent on the mineral resource sector, with little investment in the agricultural sector. Indeed agriculture in SHP remains largely subsistence based with negligible commercial outcomes. Compounding this there are few incentives for economic activity. The deterioration of the road network and the law and order situation are key constraints to production.

- Business ventures such as cattle, coffee, silkworms, etc. have proved unsustainable over the past decade in SHP due to: (i) transport and communication problems; (ii) lack of understanding about investment and replenishment strategies; (iii) trade stores attracting customers on a 'same descent' or wantok basis; and (iv) profit erosion through funnelling into customary exchange activities or debt-credit relationships.

- On the other hand, it can be argued that communities are resourceful and have an ability to survive when cut off from the country's formal economy, and that with declining revenue there is less to fight over.

- The national government and SHP provincial government are both reliant on SHP's resource wealth. It is currently estimated that 8 per cent of annual national revenue is derived from SHP's resource sector.

- This dependence on SHP's resource sector leaves both governments vulnerable to sharp economic deterioration if the resource companies withdraw suddenly or unexpectedly from SHP due to security concerns. With this is mind it is worth noting that Oil Search continues to face ongoing security problems in maintaining infrastructure, such as the pylons providing power to the Porgera gold mine. The cutting down of these pylons is typically a form of protest directed at the Papua New Guinea government over lack of service delivery and perceived inequality in distribution of resource benefits, rather than a protest directed against the company.

- The PJV and Oil Search maintain an active program of community engagement along the powerline route, so as to minimise disruptions. Felled 
power pylons give rise to lost production costs which are estimated to be in the order of \$US1.2 million per day. As it often takes several days to restore a felled pylon, regular felling of the power lines would most likely see the mine shut down.

\section{Skewed income distribution}

- The inequitable distribution of wealth has given rise to polarisation within the SHP community - the 'haves' being those who receive royalties and benefit from the Tax Credit Scheme and the 'have nots' being those outside the immediate project areas and therefore unable to access any benefits.

- Southern Highlanders living outside the resource project areas have some of the lowest income levels in Papua New Guinea as well as very poor access to basic services. The Koroba-Kopiago district in northwest of the province, for instance, is repeatedly rated as one of the poorest areas in Papua New Guinea.

- Those benefiting from SHP's resource wealth tend to invest their money outside the province (e.g. in Port Moresby real estate), leaving little money to circulate within the province. This means that there is little if any 'trickledown' effect.

- A lack of banking facilities in SHP also encourages quick consumer spending rather than re-investment within the province.

\section{Criminal encroachment on the informal economy}

- Informal market networks (and criminal networks) can become powerful in lieu of the state, with an increase in illicit commodities e.g. guns, drugs.

- Aspiration for cash is now universal with traditional barter systems breaking down (e.g. in 1971 bride-price payments typically equalled fewer than seven bride wealth items - mother of pearl shells, cowrie shell ropes or several pigs. In 2003, however, the going rate in some areas was around K10-20,000 plus pigs.)

- In some cases people are resorting to criminal activity to access cash for these payments.

\section{Trend}

SHP does not suffer from a lack of money, but from the inequitable distribution and reinvestment of that money. Unless the Papua New Guinea government takes action to prosecute egregious acts of corruption and set standards for provincial economic governance (together with increased SHP civil society demand for reform) there will be little incentive at the leadership level in SHP for change - resulting in continued conflict over economic inequality. 


\section{Environment and natural resource factors}

\section{Assumption}

Environmental degradation and depletion of renewable resources constrains economic productivity and growth; Natural resource ownership, particularly customary land ownership (and inheritance thereof), is vigorously defended in Melanesian societies.

\section{Land/resource ownership issues}

- Disputes over land tenure and natural resource ownership are pervasive.

- Land ownership can be a fluid concept. Formal land registration systems demand final adjudication on settlement, but indigenous systems require ongoing renegotiation.

\section{Land pressure and growing food security issues}

- Approximately 50 per cent of SHP is unoccupied due to difficult terrain. The most fertile land in SHP is found around Mendi, Tari and Ialibu, with the rest of the province being difficult to cultivate due to steep slopes, high altitude and increased cloud cover.

- Its been estimated that women in SHP produce 20 per cent less sweet potato for the same labour as women in more fertile areas.

- Arable land is at a premium with growing population pressure.

- SHP is vulnerable to climatic extremes (drought, excessive rainfall, frost and fire), with the majority of SHP's population having limited cash incomes to use as a buffer when subsistence food stocks run low.

- There are growing food security issues in parts of the Komo-Magarima, Mendi, Nipa-Kutubu and Koroba-Kopiago districts, due to growing population pressure, poor land potential and very low cash incomes. People in these areas were seriously affected by the 1997-1998 drought.

\section{Trend}

Depletion of existing renewable resource stocks is likely to lead to pressure to develop new resource projects to maintain the government revenue base. Clashes between customary and contemporary land tenure systems are likely to persist and any attempt to bring about land reform is likely to be strenuously resisted. Food security problems are likely to increase as population continues to grow and HIV/AIDs impacts upon adult population. 


\section{International factors}

\section{Assumptions}

International isolation reduces the capacity of the international community to influence peace-conflict dynamics within a society; proximity to violent conflict in neighbouring states/provinces can also have a destabilising effect due to trans-border phenomena (such as people movement, small arms flows and participation in war economy), especially where ethnic affiliations straddle borders.

\section{Lack of engagement with other donors}

- Apart from AusAID, the only other donor significantly engaged in SHP is the ADB through a road upgrading project. However, this project has stalled due to lack of SHP government counterpart funding commitment.

\section{Proximity to instability/conflict in neighbouring provinces}

- Whilst widespread violent conflict is not a major problem in the provinces that share a border with SHP, neighbouring provinces, such as Enga, Western and Gulf also suffer from poor governance.

\section{Illicit small arms/drugs trade}

- $\mathrm{SHP}^{\prime}$ s porous borders can act as a conduit for weapons, drugs and people.

\section{Conclusion}

Analysis of CIFP findings suggests that governance failure is essentially at the root of SHP's current problems, leading to (and allowing to flourish) both greed and grievance-driven conflict. The lack of provincial government accountability (political and administrative), social-conflict inhibitors, and an effective law and justice sector has created a permissive environment which encourages the spread of corruption, violent conflict and crime ('greed-driven conflict'), while service delivery failure, economic inequality and the perception that the state is ineffective and unresponsive has fuelled resentment and inter-group tensions ('grievance-driven conflict').

\section{ENDNOTES}

1 This assessment was prepared after the workshop and incorporates much of the material presented at the workshop. The views expressed by the author do not necessarily represent the views of the Australian Government

2 This template was developed by the Norman Paterson School of International Affairs, Carleton University, Ottawa 